\title{
甲状腺腫瘍統計と癌治療成績
}

$$
\begin{aligned}
& \text { 宮原 裕 - 田辺 修一 - 汇本 美枝 } \\
& \text { 上村 裕和 - 家根 旦有 - 田中 治* }
\end{aligned}
$$

\section{Clinical Study of Thyroid Tumors}

\author{
Hiroshi Miyahara, Shuichi Tanabe, Yoshie Emoto \\ Hirokazu Uemura and Katsunari Yane \\ (Nara Medical University) \\ Osamu Tanaka \\ (Osaka City)
}

\begin{abstract}
Five hundred eighty-five patients with thyroid tumors were surgically treated at our department between 1985 and 1997. A benign tumor was noted in 351 patients, and a malignant tumor except malignant lymphomas was observed in 234 patients. Neck X-ray, echography, CT and/or MRI were done in most patients. In 383 patients who underwent fine needle aspiration cytology, sensitivity was $91.7 \%$, and specificity was $80.4 \%$, with an accuracy value of $53.3 \%$. Pathologically, papillary and follicular cancers were diagnosed in 202 and 24 patients, respectively. In 226 patients with well-differentiated thyroid cancer, a hemithyroidectomy with isthmectomy was performed in $47.8 \%$, a subtotal thyroidectomy in $32.3 \%$ and a total thyroidectomy in $12.8 \%$. Prophylactic neck dissection including R1 or D1 was performed in 75.7\%. Neck dissection for N1, was performed in modified ND including D2a or radical ND including R2 and D2b. A pathological N positivity was shown in $66.7 \%$ of papillary cancers and $44.4 \%$ in follicular cancers. In 24 cases of extracapsular extension, local recurrence occurred in 4 cases. The ten-year survival rate was $98.5 \%$ in those with non-invasive papillary cancer and $92.9 \%$ in follicular cancer. Otherwise, it was $75.0 \%$ in patients with extracapsular invasion.
\end{abstract}

Key words : thyroid tumor, fine needle aspiration, thyroid cancer, extracapsular invasion

\section{はじめに}

甲状腺腫瘍は女性に多く発生し, 本人の自覚がなくて も感冒など他の疾患で受診した際にたまたま頸部の触診 を受け, 腺腫が指摘されることや, 最近は頸部の超音波 検査で甲状腺の異常を指摘されることも比較的多い。 た, 咽喉頭異常感が主訴となり来院し, 甲状腺腫が診断 されることもある，さらに，嗄声を主訴としその原因が 甲状腺癌であることもまれではない。
甲状腺腫瘍は境界領域とされ外科で治療されることも 多い. 事実, 日本甲状腺外科研究会 (旧甲状腺外科検討 会)の会員もほとんどが外科であり，耳鼻咽喉科で扱っ ている症例は少ない.1980年代から奈良県では甲状腺腫 瘍の手術はわれわれ耳鼻咽喉科がほとんど行って和り， 当科では頭頸部癌では最も多い喉頭癌以上に甲状腺癌の 治療を行らようになってきたため，今回1985年以降の甲 状腺腫瘍の症例を臨床的に検討し, 特に甲状腺癌での手 
術法, 頸部郭清, 再発, 治療成績についてまとめたので 報告する。

\section{対 象}

今回の検討対象は1985年 1 月から1997年12月までに奈 良県立医科大学耳鼻咽喉科・頭頸部外科で, 手術または 病理生検 (未分化癌)が行われ，病理組織診断がなされた 甲状腺腫瘍585例である．他施設を含め何らかの手術が 行われた既往があるいわゆる二次症例, および悪性リン パ腫症例11例は除外した.

\section{結 果}

1）性別，年齢

甲状腺腫瘍全症例 585 症例の5ち男性は91例, 女性は 494例であり，良性腫瘍は351例，悪性腫瘍は234例であ り，それぞれの性別，年齢(平均年齢)は表 1 亿示すごと くであった．悪性腫瘍の年齢は 8 歳女性から，84歳女性 で，平均年齢は男性で53.1歳，女性で51.4歳と両者に差 はなかった。

\section{2) 主訴(表 2)}

患者の初診時の主訴は当然前頸部腫脹が最も多かった （良性で $47.9 \%$ ，悪性で70.9\%)が，次いで良性腫瘍の場 合は咽喉頭異常感が31.9\% と比較的多かった．嗄声が主

表 1 甲状腺腫瘍の良悪と性・年齢

\begin{tabular}{|c|c|c|c|}
\hline & & 例数 & 年齢 (平均年齢) \\
\hline \multirow[t]{2}{*}{ 良性 } & 男性 & 50 & $28 \sim 68 \quad(50.6)$ \\
\hline & 女性 & 301 & $22 \sim 72(48.4)$ \\
\hline \multirow[t]{2}{*}{ 悪性 } & 男性 & 41 & $12 \sim 83(53.1)$ \\
\hline & 女性 & 193 & $8 \sim 84(51.4)$ \\
\hline
\end{tabular}

表 2 主 訴

\begin{tabular}{|c|c|c|}
\hline & \multicolumn{2}{|c|}{ 例 数 (\%) } \\
\hline & 良性 & 悪性 \\
\hline 前頸部腫脹 & $168(47.9)$ & $166(70.9)$ \\
\hline 嗄声 & $28(8.0)$ & $19(8.1)$ \\
\hline 咽喉頭異常感 & $112(31.9)$ & $19(8.1)$ \\
\hline 嚥下障害 & $0(0)$ & $5(2.1)$ \\
\hline 血痰 & $0(0)$ & $3(1.3)$ \\
\hline その他 & $43(12.3)$ & $22(9.4)$ \\
\hline 計 & 351 & 234 \\
\hline
\end{tabular}

訴となっていた症例も良性，悪性とも8\%にみられた。 悪性の場合，嗄声の原因は全例が反回神経麻痺によるも のであった。

3 ）診断法，特飞穿刺吸引細胞診

甲状腺腫瘍の患者の診察に当たって通常は問診, 頸部 触診ののち，頸部軟線 $\mathrm{X}$ 線撮影，超音波検査，穿刺吸引 細胞診(以下 FNA)を行っている。さらに，CT，MRI， シンチグラム (I，Tc，Tl など)などを行い，急速に増大 し，悪性リンパ腫や未分化癌が疑われる症例では open biopsyを行らこともあった。

FNAを行い得た 383 例の術前診断と術後病理診断と の関係を調べてみると，表 3 のごとくで class I，II を 良性， $N, V$ を悪性として判定すると，悪性腫瘍の sensitivityは91.7\%(122/133)，良性腫瘍の specificityは 80.4\%(82/102)であった。したがって， diagnostic accuracy は53.3\%であった。ただし， class III が148例と 38.6\%を占めていた.

\section{4 ) 病理組織学的分類}

手術および生検により確かめられた甲状腺腫瘍の病理 組織学的分類は表 4 のごとくで，良性では濾胞腺腫が約

表 3 穿刺吸引細胞診

\begin{tabular}{rrrrr}
\hline \hline & \multicolumn{2}{c}{ 例 } & 数 & \multirow{2}{*}{ 計 } \\
\cline { 2 - 4 } & 良性 & 悪性 & \\
\hline class & I & 17 & 3 & 20 \\
II & 65 & 17 & 82 \\
III & 119 & 29 & 148 \\
IV & 4 & 13 & 17 \\
V & 7 & 109 & 116 \\
\hline 計 & 212 & 171 & 383
\end{tabular}

表 4 病理組織学的分類 $(n=585)$

\begin{tabular}{|c|c|c|}
\hline & 病理組織診断 & 例 数 \\
\hline \multirow[t]{3}{*}{ 良性 } & 濾胞腺腫 & 226 \\
\hline & 腺腫様甲状腺腫 & 111 \\
\hline & 雯胞 & 14 \\
\hline \multirow[t]{5}{*}{ 悪性 } & 乳頭癌 & $202(86.3 \%)$ \\
\hline & 濾胞癌 & $24(10.3)$ \\
\hline & 末分化癌 & $5(2.1)$ \\
\hline & 䯣様癌 & $1(0.4)$ \\
\hline & その他 & $2(0.9)$ \\
\hline
\end{tabular}


2/3を占め226例であった．悪性では乳頭癌がほとんど を占め202例であった．次いで濾胞癌が24例, 未分化癌 が 5 例であった。髄様癌は 1 例にしかすぎなかった。な お。，悪性リンパ腫は除外されている.

5 ) 甲状腺腫瘍の手術法

甲状腺腫瘍の手術については良性の場合はほとんどの 例に扣いて甲状腺半葉切除術がなされていた。悪性の場 合, 未分化癌は生検, 化学療法, 放射線治療が行われた 2 例之髄様癌, 未分化癌半切例は手術後に判明し, 他の 2 例の未分化癌は甲状腺全摘術が行われていた。 その他 扁平上皮癌 1 例, 好酸性細胞癌 1 例があった。 したがっ て, それらを除いた分化癌(乳頭癌, 慮胞癌) 226 例の手 術についてまとめてみた。それらの術前, 術後の TN 分類を表 5,6 亿示した. 局所については表 7 に示すよ らに最も多かったのが半葉切除術であり, $47.8 \%$ を占め た. 次いで亜全摘術 $32.3 \%$, 全摘出術 $12.8 \%$ の順であっ た. 超音波検查や CT で反対葉に結節病変を認め, 腺内 転移も疑われる場合には反対葉の結節に対しては核出術 がなされた症例が11例あった。実際に腺内転移であった 症例は 7 例であった. 甲状腺峡部を中心に発生した癌腫 に対して峡部切除術がなされたのが 4 例あった。

頸部郭清術については75.7\%(171/226)の症例で行わ れ，術前 N0 でFNA や他の画像診断で悪性が疑われた 症例では予防的頸部郭清術が汪とんどの例で行われた。 しかし, 郭清範囲はD1を中心としたものが多かった. 術前にN1であった例では modified ND (D2a 郭清を含 む) や radical ND (D2b 郭清を含む) や両側頸部郭清術

表 5 甲状腺乳頭癌の $\mathrm{TN}, \mathrm{pTN}$ 分類 $(\mathrm{n}=202)$

\begin{tabular}{rrrrr}
\hline \hline & N0 & N1a & N1b & 計 \\
\hline T1 & 14 & 7 & 0 & 21 \\
T2 & 97 & 22 & 4 & 123 \\
T3 & 25 & 16 & 5 & 46 \\
T4 & 7 & 0 & 5 & 12 \\
\hline 計 & 143 & 45 & 14 &
\end{tabular}

\begin{tabular}{cccrr}
\hline & $\mathrm{pN} 0$ & $\mathrm{pN} 1 \mathrm{a}$ & $\mathrm{pN} 1 \mathrm{~b}$ & 計 \\
\hline $\mathrm{T} 1$ & 10 & 6 & 5 & 21 \\
$\mathrm{~T} 2$ & 49 & 5 & 69 & 123 \\
$\mathrm{~T} 3$ & 13 & 1 & 32 & 46 \\
$\mathrm{~T} 4$ & 4 & 0 & 8 & 12 \\
\hline 計 & 76 & 12 & 114 &
\end{tabular}

表 6 甲状腺濾胞癌の $\mathrm{TN}, \mathrm{pTN}$ 分類 $(\mathrm{n}=24)$

\begin{tabular}{crccr}
\hline \hline & N0 & N1a & N1b & 計 \\
\hline T1 & 1 & 1 & 0 & 2 \\
T2 & 10 & 1 & 0 & 11 \\
T3 & 11 & 0 & 0 & 11 \\
T4 & 0 & 0 & 0 & 0 \\
\hline 計 & 22 & 2 & 0 & \\
& & & & \\
\hline & pN0 & pN1a & pN1b & 計 \\
\hline T1 & 1 & 1 & 0 & 2 \\
T2 & 6 & 1 & 4 & 11 \\
T3 & 11 & 0 & 0 & 11 \\
T4 & 0 & 0 & 0 & 0 \\
\hline 計 & 18 & 2 & 4 &
\end{tabular}

表 7 甲状腺分化癌の手術治療 (1)

\begin{tabular}{lc}
\hline \hline & 例数 \\
\hline 半葉切除術 & $108(47.8 \%)$ \\
亜全摘術 & $73(32.3)$ \\
全摘出術 & $29(12.8)$ \\
半葉切除術十核出術(反対葉) & $11(4.9)$ \\
峡部切除術 & $4(1.8)$ \\
核出術 & $1(0.4)$ \\
\hline \multicolumn{2}{l}{} \\
\end{tabular}

表 8 甲状腺分化癌の手術治療 (2)

\begin{tabular}{cc}
\hline \hline & 例数 \\
\hline 頸部郭清術施行 & 171 \\
部分郭清術 (R1, D1 郭清を含む) & 119 \\
modified ND (D2a 郭清を含む) & 29 \\
radical ND (R2, D2b 郭清を含む) & 13 \\
両側頸部郭清術 & 10 \\
郭清術なし & 55 \\
\hline
\end{tabular}

が行われた(表 8 , 図 $1^{11)}$ ).

頸部郭清術がなされた症例での実際のリンパ節転移陽 性率について調べてみると表 9 のごとくで, 乳頭癌では 術前 $\mathrm{N} 0$ 症例 105 例で病理的に陽性であったのは70例 (66.7\%)であった。濾胞癌では $\mathrm{N} 0$ 症例 9 例中陽性で あったのは 4 例(44.4\%)であった。.な拉, それらの症例 

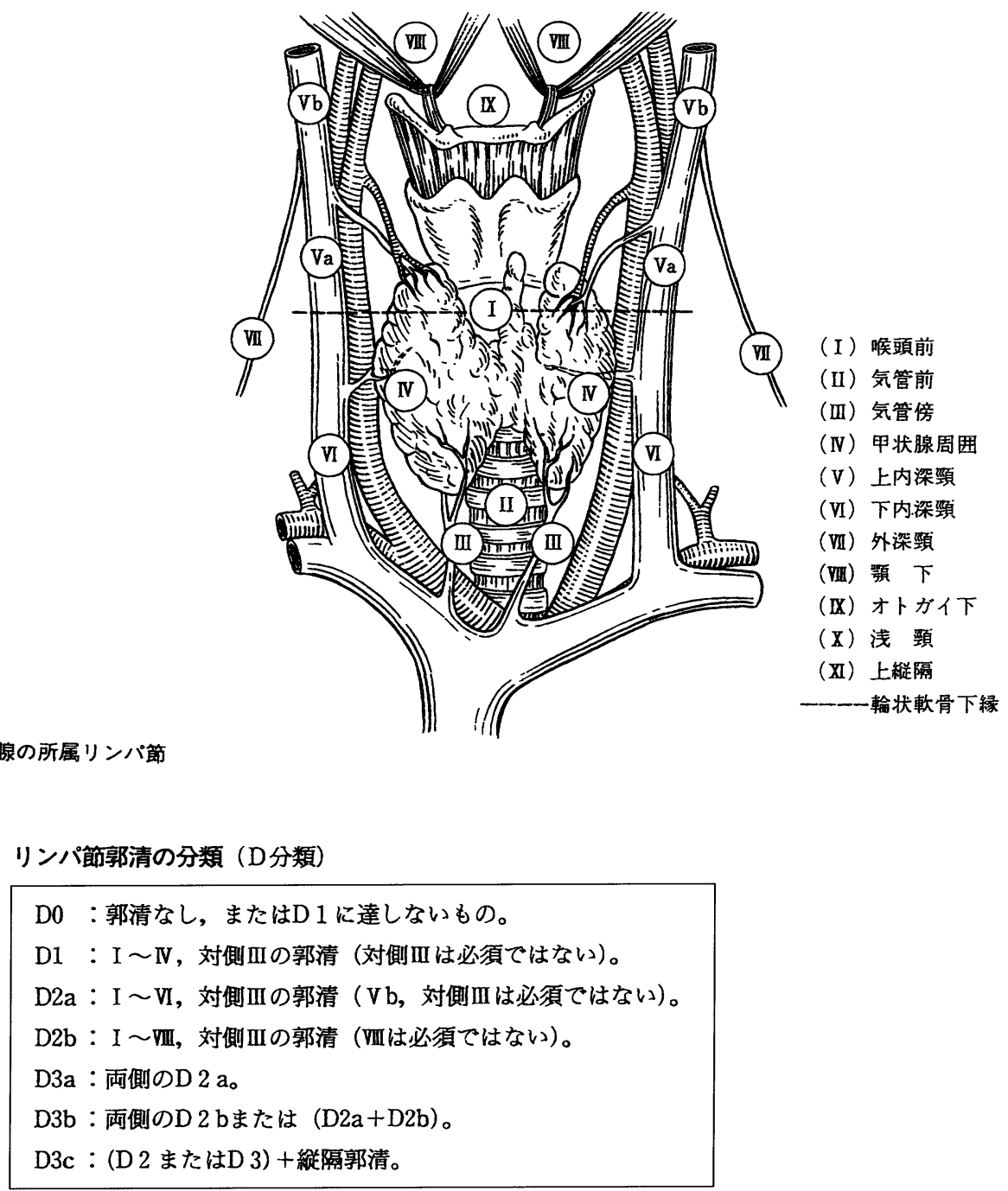

注：ここでいう対側而とは甲状腺下縁より尾側をいう。

図 1 甲状腺の所属リンパ節とリンパ節郭清の分類 (甲状腺外科検討会；1996 ${ }^{1)}$ より転載）

でさらに術後経過中に頸部リンパ節再発をきたしたのは 乳頭癌では 7 例に認め, 1 例を除いて他はすべて $\mathrm{pN} 1 \mathrm{~b}$ であった症例であった．濾胞癌ではそのような再発は認 めていない。

\section{6 ）治療成績・予後}

甲状腺分化癌の乳頭癌, 濾胞癌治療後の予後について であるが，現在までに経過が追跡され，再発や遠隔転移 のない症例は201例であり，反対に遠隔転移がみられて いるのは 7 例である.それらの内訳は表 10 こごとくで甲 状腺拉よび頸部リンパ節に再発し，しかも肺転移をきた
したのが 2 例, 頸部リンパ節に再発し肺転移をきたした 症例は 3 例で, 肺転移単独例はなく, 骨転移が 2 例であっ た.

頸部リンパ節再発をきたしたのは乳頭癌で郭清術施行 例では16例(10.0\%), 非施行例で 3 例 (7.1\%), 濾胞癌 で郭清術施行例, 非施行例ではともに認めていない(表 11).

初回手術時に被膜外浸潤があり, 気管, 食道筋層, 輪 状軟骨, 甲状軟骨, 喉頭への切除が同時に行われた24例 の切除法とその後の局所再発について検討した. 気管軟 
表 $9 \mathrm{~N} 0$ 症例に対する頸部郭清術施行と頸部リンパ節転 移 $(\mathrm{pN})$ 陽性率

（1）乳頭癌 N0 症例での頸部郭清術施行例の TN 分類 $(n=105)$

\begin{tabular}{crccc}
\hline \hline & $\mathrm{pN} 0$ & $\mathrm{pN} 1 \mathrm{a}$ & $\mathrm{pN} 1 \mathrm{~b}$ & 計 \\
\hline $\mathrm{T} 1$ & 7 & 2 & 2 & 11 \\
$\mathrm{~T} 2$ & 20 & 1 & 49 & 70 \\
$\mathrm{~T} 3$ & 5 & 0 & 13 & 18 \\
$\mathrm{~T} 4$ & 3 & 0 & 3 & 6 \\
\hline 計 & 35 & 3 & 67 &
\end{tabular}

（2）濾胞癌 N0 症例での頸部郭清術施行例の TN 分類 $(\mathrm{n}=9)$

\begin{tabular}{ccccc}
\hline & $\mathrm{pN} 0$ & $\mathrm{pN} 1 \mathrm{a}$ & $\mathrm{pN} 1 \mathrm{~b}$ & 計 \\
\hline $\mathrm{T} 1$ & 1 & 0 & 0 & 1 \\
$\mathrm{~T} 2$ & 2 & 1 & 3 & 6 \\
$\mathrm{~T} 3$ & 2 & 0 & 0 & 2 \\
$\mathrm{~T} 4$ & 0 & 0 & 0 & 0 \\
\hline 計 & 5 & 1 & 3 &
\end{tabular}

表10 分化癌での再発・遠隔転移 $(n=226)$

\begin{tabular}{cr}
\hline \hline & 例数 \\
\hline 再発・遠隔転移なし & 201 \\
再発・遠隔転移あり & 25 \\
甲状腺のみ & 3 \\
甲状腺十頸部リンパ節 & 2 \\
甲状腺十頸部リンパ節十肺 & 2 \\
気管 & 1 \\
頸部リンパ節のみ & 12 \\
頸部リンパ節十肺 & 3 \\
骨 & 2
\end{tabular}

骨を合併切除し，気管粘膜は残した気管軟骨切除，食道 筋層への浸潤のため食道粘膜は残した食道笳層切除, 気
表11頸部郭清術と頸部リンパ節転移再発

(1) 乳頭癌 $(n=202)$

\begin{tabular}{|c|c|c|}
\hline & \multicolumn{2}{|c|}{ 頸部リンパ節再発 } \\
\hline & $(+)$ & $(-)$ \\
\hline $\begin{array}{r}\text { 頸部郭清術施行 } \\
(\mathrm{n}=160)\end{array}$ & $16 / 160(10.0)$ & $144 / 160(90.0)$ \\
\hline $\begin{array}{l}\text { 非施行 } \\
(\mathrm{n}=42)\end{array}$ & $3 / 42(7.1)$ & $39 / 42 \quad(91.2)$ \\
\hline
\end{tabular}

（2）濾胞癌 $(\mathrm{n}=24)$

\begin{tabular}{rcc}
\hline & \multicolumn{2}{c}{ 頸部リンパ節再発 } \\
\cline { 2 - 3 } & $(+)$ & $(-)$ \\
\hline 頸部郭清術施行 \\
$(\mathrm{n}=11)$ \\
$\begin{array}{r}\text { 非施行 } \\
(\mathrm{n}=13)\end{array}$ & $0 / 11(0.0)$ & $11 / 11(100.0)$ \\
& $0 / 13(0.0)$ & $13 / 13(100.0)$
\end{tabular}

管軟骨と粘膜も同時に切除し開空した気管孔造設と分け て表12に示した．乳頭癌では気管軟骨切除のみ，気管軟 骨・食道筋層切除例, 喉頭合併切除例では再発はなく, 気管孔造設例 5 例中 2 例が再発している. 食道筋層切除 2 例のらち 1 例が再発している。一方, 濾胞癌では気管 軟骨切除のみの 2 例中 1 例に再発を認めている.

10 年以上経過の追えた症例174例を対象にして, 生存 率を被膜外浸潤例と非浸潤例で分けてみると，非浸潤例 の150例では 10 年生存率 $98.0 \%$ で, 乳頭癌(134例) で98.5 $\%$, 濾胞癌(14例) で92.9\%であった(因 2 ). 気管・食道 浸潤例24例では75.0\%で, 乳頭癌 (20例)で70.0\%, 濾胞 癌（4例）で100\%であった(図 3 )。ささらに，気管・食道 浸潤乳頭癌20例で病理組織学的に高分化型度と低分化型 とで予後をみると，高分化型16例では81.3\%，低分化型 4 例では25.0\%と低率であった(図 4 ).

な技，未分化癌の 5 例は全例 1 年以内に死亡した。手 術可能例は 3 例にすぎなかったが，そのうち 1 例は半切

表12 浸潤部位と切除範囲と局所再発

\begin{tabular}{|c|c|c|c|c|}
\hline \multirow{2}{*}{ 切除/再建法 } & \multirow{2}{*}{$\frac{\text { 例 }}{\text { 乳頭癌 }}$} & \multirow{2}{*}{$\begin{array}{l}\text { 数 } \\
\text { 濾胞癌 }\end{array}$} & \multicolumn{2}{|c|}{ 局所再発 } \\
\hline & & & 乳頭癌 & 濾胞癌 \\
\hline 気管軟骨切除 & 9 & 2 & $0 / 9$ & $1 / 2$ \\
\hline 気管軟骨・食道笳層切除 & 2 & & $0 / 2$ & \\
\hline 気管軟骨・粘膜切除 $\rightarrow$ 気管孔造設 & 5 & 1 & $2 / 5$ & $0 / 1$ \\
\hline 食道筋層切除 & 2 & 1 & $1 / 2$ & $0 / 1$ \\
\hline 咽喉頭全摘出術 $\rightarrow$ 食道再建術 & 2 & & $0 / 2$ & \\
\hline
\end{tabular}




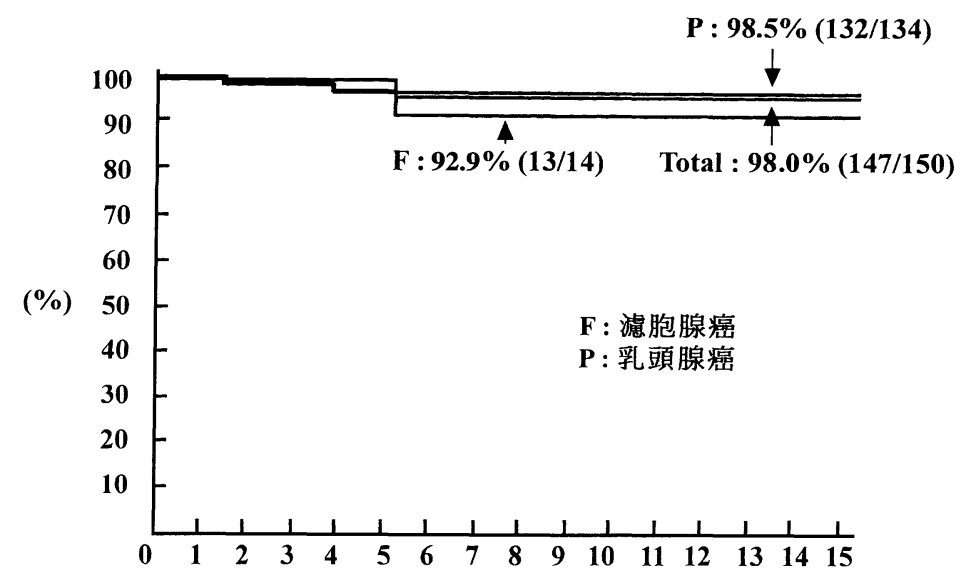

(年)

図 2 生存曲線 1

～非浸潤例～

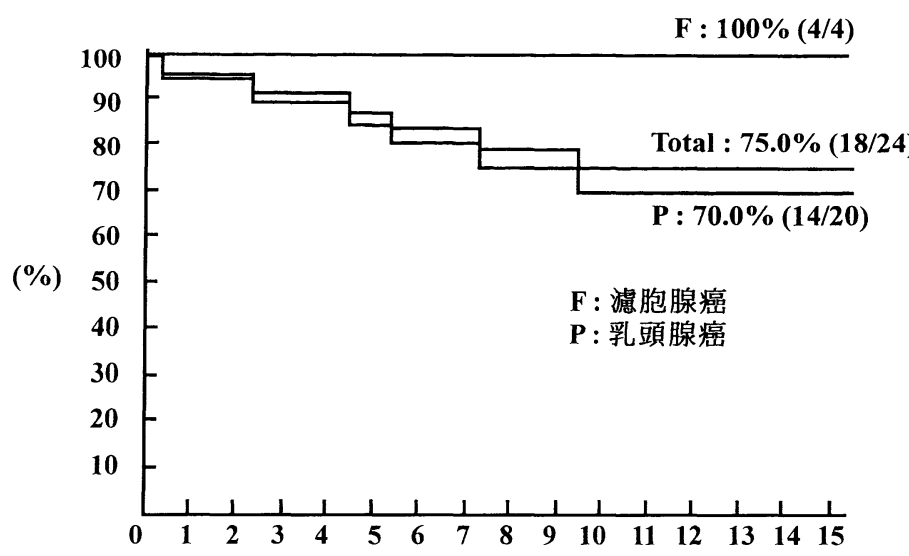

(年)

図 3 生存曲線 2

～気管・食道浸潤例 $(1)$

後末分化癌と判明した症例である.

\section{考察}

甲状腺腫場は女性に多く発生し，たまたま頸部の触診 を受け，腺腫が指摘されることや，咽喉頭異常感が主訴 となり来院し，甲状腺腫が診断されることもある．さら に, 最近は超音波検査が開業医のレベルでも沉用される ようになり, 機器の精度が向上したこともあり, $1 \mathrm{~cm}$ 以下の腫瘤の存在や，小石灰化が診断される機会が増兄 ている．とのため，われわれ耳鼻咽喉科を紹介受診する
患者も漸増している.耳鼻咽喉科・頭頸部外科医として は頸部腫瘤以外の症状であっても必ず頸部触診は怠らな いようにして扔かなければならないと考觉る2).

患者の主訴は当然甲状腺腫大であることが多かったが， 嗄声が主訴であり喉頭鏡検査で喉頭麻痺の所見を示し, その原因が甲状腺癌であることもまれではない，癌腫で 初診時喉頭麻痺を認めたのは25例であったが，その病理 組織は18例が乳頭癌で， 5 例が未分化癌， 1 例が扁平上 皮癌であった．未分化癌は全例が最初から少なくとも一 側の喉頭麻㽻をきたしていた。 


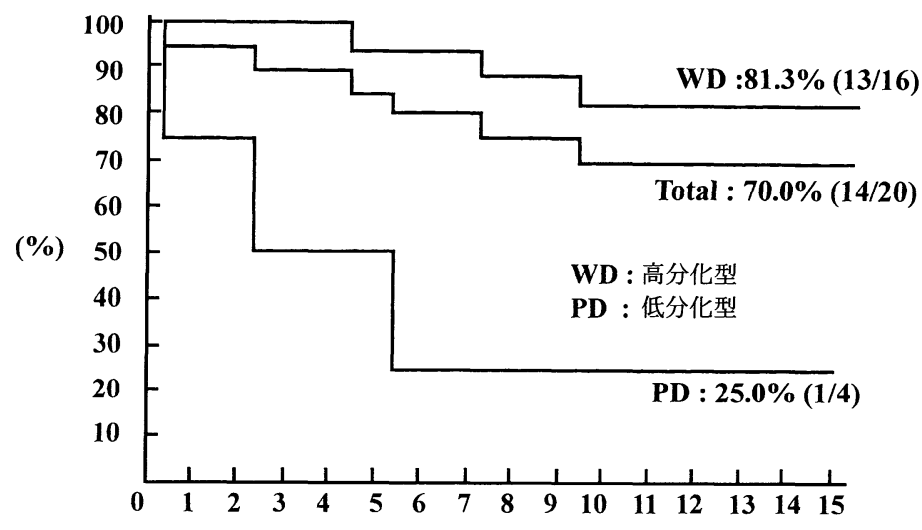

(年)

図 4 生存曲線 2

～気管 $\cdot$ 食道漫潤例 $(2) \sim$

甲状腺腫瘍585例の女性対男性の比は 5〜6:1であっ たが，男性では悪性のことが多い(45\%)結果であった，

質的誩断として有力な手段となる FNA については， 悪性であるといら sensitivity は $91.7 \%$ と高いが，滤胞 癌は FNA では確定診断が困難であるので注意を要する. 今回のわれわれの結果では class III のうち80.4\%(119/ 148）が病理組織診で良性と判明し，良性疾患全体に占め る class III の割合は56.1\%(119/212) と高い比率であっ た．その判定基準については細胞診病理医の考光方も反 映されて扣り, 今後の問題となった。

良性では濾胞腺腫が $64.4 \%$, 悪性では乳頭癌が占める 割合が $86.3 \%$ で注とんどを占め，次いで濾胞癌が $10.3 \%$ であり，これら分化癌の両者で実に $97 \%$ 占めた。これ はこれまでの報告の多くとほぼ一致していた。また，わ が国の主要機関の症例をもとにした甲状腺悪性腫瘍登 録)(1977〜1997)によると，31，364例のらち，乳頭癌が $82.6 \%$, 濾胞癌が $11.6 \%$ であり, これら分化癌の両者で 実に $97 \%$ を占め，未分化癌は $1.7 \%$, 髄様癌は $1.4 \%$ にす ぎず，われわれと同じ傾向であった.

当科では襄胞であることがはっきりしている例では， 内容液の吸引と $99 \%$ ェタノール注入 $(\leqq 1.0 \mathrm{ml})^{4)}$ を行っ ている．良性腫瘍であることが FNA ではっきりしてい る例でも，腫瘤がある程度大きいと抑制療法 (甲状腺剤) を行う例もあるが，経過観察よりは患者の希望を入れ， インフォームドュンセントの上，積極的に手術している ことが多い，今日な和甲状腺良性腫瘍(非機能性)に対し ての治療法は外科医，耳鼻咽喉科医に統一された指針は
決まっていないといえる。

一方, 甲状腺乳頭癌, 濾胞癌の手術法5)6) については, これも時代の変遷とともに大きく変わってきたが，われ われは少なくとも峡部を含む半葉以上の切除を基本とし たが，対側甲状腺はできる限り温存する傾向であった． 甲状腺全摘例は $13.8 \%$ にすぎなかった。 しかし，これま での経過観察中に残存甲状腺に再発し全摘となった例は ほとんぞない，今後もこれまで以上に拡大摘出を行らつ もりはない。

手術前に頸部リンパ節転移を触知しなかった乳頭癌, N0 例に対する頸部郭清術は気管前, 傍気管リンパ節を 含めて郭清する例が多かったが，原発巣にかかわらず気 管傍リンパ節への転移傾向は乳頭癌で $67 \%$ ときわめて高 く, 滤胞癌でも $44 \%$ と高かった。したがって, N0症例 では気管前・傍リンパ節郭清が予防的郭清術として適切 と考えられた。ところで，杉野ら゙は FNA が導入され る以前に術前に良性と判断し, リンパ節郭清術をせずに 甲状腺切除のみを行い術後乳頭癌と判明した症例と, 最 初から定型的リンパ節郭清を行った乳頭癌症例とでその 後のリンパ節再発の頻度を調べている.それによると， リンパ節再発の頻度がそれぞれ $9.7 \%(19 / 196) ， 11.2 \%$ (88/783)であり，両者に有意な差がなかったことから， 術前に良性腫瘍として手術された乳頭癌に対して早急に 再手術を施行する必要はないと述べている，また，顕微 鏡的なリンパ節転移が必ずしもすべて臨床的に顕性と なってくるのではないといらこの癌の特異な生物学的悪 性度は従来から指摘されて拈り，今後さらにこの方面の 
研究が進歩することを期待したい．

ところで, 甲状腺乳頭癌および濾胞癌の気管や喉頭, 食道筋層などの周囲臓器への非浸潤例では予後はきわめ て良好であった．気管・食道筋層浸潤例では気管軟骨切 除 (気管層状切除) $)^{8)}$ ，食道筋層切除，気管開空術など8) 10) が行われる。 また，喉頭への浸潤例の一部では喉頭部分 切除術中喉頭全摘術が行われる11).

たとえ気管・食道筋層浸潤例で気管開空せざるを得な くても, 食道筋層切除の際に断端に癌腫を残さないよう にする適切な切除により良好な予後が期待される。ささら に，それらの手術手技もさることながら甲状腺乳頭癌の 気管・食道筋層浸潤は分化型では 10 年生存率が $81.3 \%$, 低分化型では $25 \%$ と全く低率で，分化度によって予後に 大きな差がみられたことにより，特に低分化乳頭癌の場 合はより拡大的な切除が必要となる. しかし，術前に FNA では分化度までは判定できないので, 術後のより 厳重な経過観察を要する。

また，今回は検討しなかったが，分化癌から急速に未

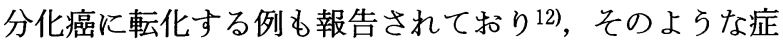
例には迅速，かつ適切な診断が要求される。

\section{まとめ}

1985年から1997年までに当科で主に手術加療された甲 状腺腫瘍585症例について臨床的に検討した。

良性，悪性ともに女性が男性に比べて多かった．男性 では悪性の比率が高かった。癌症例の手術では甲状腺は 峡部を含む半葉以上の切除とし，なるべく甲状腺全摘は 厳選する術式が選択されたが，被膜外浸潤のない乳頭癌， 濾胞癌ではきわめて良好な長期予後が得られた。気管, 食道筋層への被膜外浸潤例に扣いても適切な切除を行う ことで良好な予後が得られると考兄られた．しかし，被 膜外浸潤があり，低分化型乳頭癌の症例は予後が不良な 例もみられた。

頸部郭清術は予防的郭清術を含めて約 $3 / 4$ の症例に行 われた. 乳頭癌, 濾胞癌 $\mathrm{N} 0$ 症例でも比較的高率に気管
前・傍リンパ節転移をきたしているので同部の郭清は 行っておくのがよい.

なお本論文の要旨は第60回耳鼻咽喉科臨床学会 $(1998 ，$ 岡山 にて報告した。

\section{参考文献}

1) 甲状腺外科検討会：甲状腺癌取扱い規約(第 5 版)（甲状腺 外科検討会編)．6頁，金原出版，東京，1996.

2 ) 田中 治, 山本史郎, 家根旦有, 他: 最近 5 年間の甲状腺 腫瘍74症例について一臨床統計招よび補助診断一. 耳鼻 臨床 $80: 1691 \sim 1699,1987$.

3 ) 甲状腺悪性腫瘍登録委員会：甲状腺悪性腫瘍登録集計(1977 ～1997)，第32回甲状腺外科研究会抄録集別冊（甲状腺悪性 腫瘍登録委員会編)．165～178頁， 1999.

4 ）宮原 裕, 家根旦有, 上村裕和：頭頸部腫場への経皮的工 タノール注入療法. 耳鼻臨床 $93: 8 \sim 9,2000$.

5 ）森一功, 中島 格：甲状腺分化癌の外科的治療. JOHNS $13: 1349 \sim 1356,1997$.

6）永原國彦：follicular variantを除く濾胞癌の再検討一甲 状腺悪性腫瘍725例の検討一. 耳鼻 $36 ： 878 \sim 881,1990$.

7）杉野公則, 㺯 吉焕, 伊藤國彦, 他 : 甲状腺乳頭癌非郭清 例に怙ける頸部リンパ節再発について。目外会誌 94 ： 1108〜1111, 1993.

8 ）山本 艺, 和田 尚, 野口真三郎, 他 : 甲状腺癌気管浸潤 例飞対する気管層状切除術. 内分泌外科 $7: 51 \sim 55,1990$.

9 ）海老原敏：周囲組織に浸潤した甲状腺癌. 外科 $44: 1339$ $\sim 1342,1993$.

10）上村裕和，家根旦有，宮原 裕：甲状腺癌気管浸潤例の気 管切除範囲に関する検討. 頭頸部腫瘍 $26 ： 90 \sim 94,2000$ 。

11）宮原 裕, 佐藤武男, 吉野邦俊, 他 : 甲状腺悪性腫瘍の臨 床的検討. 耳展 $34: 311 \sim 317,1991$.

12）永原國彦：未分化転化した甲状腺癌の治療. JOHNS 13 ： 1357 1360, 1997.

原稿受付 : 平成12年 4 月 6 日 原稿採択 : 平成 12 年 6 月 7 日 別刷請求先: 宮原 裕 干558-0056 大阪市住吉区万代東3-1-56
大阪府立病院耳鼻咽喉科 